\title{
Can Climate Change Affect Agricultural Output in Nigeria?
}

\author{
Deborah Omotsefe ODEJIMI $\mathrm{PhD}^{1 *} \quad$ Patience Lilian OZOR ${ }^{2}$ \\ 1. Department of Economics and Development Studies, Igbinedion University, Okada, Edo State, Nigeria \\ 2. Department of Economics and Development Studies, Igbinedion University, Okada, Edo State, Nigeria
}

\begin{abstract}
Changes in the climatic conditions in Nigeria is posing serious threat to the economic survival of the nation. This study, the effect of climate change on agricultural output in Nigeria is important and critical in determining the policy direction of the state especially given the negative impact it has on the source of livelihood of her citizenry. The major objective was to find out how climate change impacted on agricultural production. An econometric model was employed as a guide in estimating the relationship among the variables. The findings revealed a positive relationship exist between government expenditure, exchange rate, rainfall and agricultural output. However, temperature and inflation had negative relationship but were significant at $5 \%$ and $10 \%$ respectively. It was recommended that government increase its budgetary allocation to the agricultural sector, enact policies deliberately targeted at mitigating the effect of climatic change on agriculture, empower farmers via subsidies, improved seedlings and soft loans through the relevant agencies, and invest in irrigation so farmers would not only depend on rainfall to grow their crops.
\end{abstract}

KEY WORDS: Nigeria, Climate change, Temperature, Agricultural output, Rainfall, Government. DOI: $10.7176 / \mathrm{EJBM} / 11-6-08$

\section{INTRODUCTION}

Agriculture is the engine of economy-wide performance because the sector's growth exhibits a higher multiplier than growth in other sectors especially in countries where its budgetary allocation share is large. Despite the growing knowledge of climate change and its impacts on agriculture, many uncertainties remain. The agricultural sector in Nigeria is particularly important for the country's food security, provision of raw materials for industries, foreign exchange earnings, employment and growth prospects. Agriculture as the mainstay of Nigeria provides employment, food and shelter for over $60 \%$ of the populace. However, investment in agriculture has not been not encouraging as only about $3 \%$ of total government expenditure is allocated to the sector. It is important to note that food production can no longer keep pace with population growth in Nigeria and that food shortage is believed to be largely caused by several factors including climate change.

Nigeria's government have consistently paid lip service to the Millennium Development Goals (MDGs) in terms of budgetary allocation to agriculture. This has hampered national development and eradication of poverty from the land. Not surprising that even the meagre allocation to that sector is spent on recurrent expenditure like travelling allowances, official entertainments and others at the expense of building dams and other infrastructural facilities that would support all-year-round crop production. The major issues that have dominated international development debates are climate change and the survival of agricultural production. One of the targets of the Millennium Development Goals (MDGs) is to reduce world hunger and poverty by ensuring sustainable agricultural production to feed the poor and create means of livelihood.

A critical look at the Central Bank of Nigeria (CBN) 2018 documents show that Nigerian government allocated a paltry $1.8 \%$ of its budget to agriculture in $2011,1.6 \%$ in $2012,1.7 \%$ in 2013 and $1.4 \%$ in 2014. In 2015, budgetary allocation to the agricultural sector was $0.9 \%$, while in 2016 and 2017 it rose insignificantly to $1.3 \%$, and $1.8 \%$ respectively. In 2018 , there was a slight increase to $3.2 \%$, which is still far cry from the benchmark of $10 \%$ federal budget allocation stipulated at the African Union Declaration on Agriculture and Food Security in 2003 in Maputo, Mozambique. Nigeria was a signatory to the Maputo and Malabo declarations in 2003 and 2014 respectively. The declaration contained several important decisions with respect to agriculture, but more importantly was the commitment to the allocation of at least $10 \%$ of federal budgetary allocation to agriculture and rural development policy within five years. Fifteen years after the declaration, Nigeria is yet to measure up in terms of commitment of resources to the sector as indicated in the 2018 budget of 3.2\% to the agricultural sector. (Emejor, 2018).

With the current government drive towards the diversification of the Nigerian economy in line with the current economic realities, it has become pertinent to evaluate the impact, if any, of the current climatic changes in Nigeria and its impact on our agricultural output which is our mainstay and by extension our tool for economic development. This study assesses the impact of climate change on agricultural output in Nigeria. 


\section{LITERATURE REVIEW}

Agriculture is a stage of development in the history of human civilization whereby farming of domesticated species created food and economic surpluses that nurtured the development of civilization. Agriculture is the main source of livelihood for most rural communities in developing countries especially the Sub-Saharan Africa (SSA); it provides food and employment to about $60-70 \%$ of the population. It is a vital source of raw materials used in the processing industries and source of foreign exchange earnings for the country making it a very viable sector of the economy (Mayong et al. 2005, Mohammed-Lawal and Atte 2006).

World's climate over the centuries has been in constant change, with rainfall, rather than temperature being the most relevant climatic limiting factor of food production ((Molua, 2009, Warren, 2005). According to Adejuwon (2004) the issue of climate change has become more threatening not only to the sustainable development of socioeconomic and agricultural activities of any nation but to the totality of human existence. Overcoming challenges posed by climate change related to agricultural production which in turn affect economic development will depend on farmer's use of technology. (Kurukulasuriya and Mendelsohn, 2007).

Nigeria is blessed with very diverse and rich vegetation capable of supporting large population of livestock. The ecological zones in Nigeria are also very diverse with the semi-arid (Sahel savannah) zone, Guinea Savannah as well as Forest and Mangrove zones. A few variations exist within each ecological zone. The ecology and trends in precipitation in a region determines what kind of farming system the people will practice, their food preference and how they make use of natural resources in their environment (Azih, 2008, Aregheore, 2011).

Climate change has become a headline issue in policy statements from governments and civil society actors. In the agricultural sector, most agencies have started re-thinking their agricultural portfolios in relation to the projected climate change impacts. It could be argued that climate change presents a window of opportunity to open up policy spaces for dealing with uncertainty and complexity of agri-food systems. Future impacts are projected to worsen as the temperature continues to rise and as precipitation becomes more unpredictable. Among the many adverse impacts of climate change, the risk to agriculture is considered most significant (Cline 2007, Seo and Mendelsohn, 2008). Conversely, according to Intergovernmental Panel on Climate Change (IPCC, 2007), agriculture itself is responsible for over a quarter of total global greenhouse gas emissions because agriculture is highly greenhouse intensive. Nevertheless, world survival is hinged on agriculture.

Countries that are experiencing drought, especially those in the Middle East and North Africa are likely to experience declines in agricultural yields, resulting in negative effects on rural incomes and hence food security. Climate change manifests itself with temperature increases, changes in precipitation, a rise in sea levels thereby increasing the intensity of such natural hazards as storms, floods and droughts, (IPCC, 2007). According to Enete (2014), climate change affects agriculture in a number of ways, including through changes in average temperatures, changes in precipitation patterns, rainfall, and climate extremes (e.g., heat waves); changes in pests and diseases; changes in atmospheric carbon dioxide and ground-level ozone concentrations and changes in the nutritional quality of some foods. Kuta (2011), states that adverse changes in weather affects livestock, fisheries, forestry, including rice which is the world's most important crop for ensuring food security. According to the Federal Government of Nigeria (FGN) over the past thirty years, fishing and farming activities on the lake Chad has drastically reduced as over $90 \%$ of the Lake Chad water has been lost to drought.

Abul-Quasem et. al (2011) stated in their study that climate change could reduce crop yield and zones that are vulnerable to drought could have a drastic reduction in their level of productivity and this can lead to threat of national food security and loss in raw materials export earnings. According to research, climate change could influence food production adversely due to resulting geographical shifts and yield changes in agriculture, reduction in the quantity of water available for irrigation and loss of land. With the increasing changes in soil moisture and temperature, floods and drought could be on the increase in some places and these will affect the natural ecosystems, food supplies, human and livestock health, water resources among others (Apagu, Kwami and Garba, 2011).

A study carried out on the effects of climate change on agricultural production among farmers in Kwali Area Council of the Federal Capital Territory, Abuja Nigeria, reveal that rise in temperature, solar radiation, low rainfall and the presence of excessive nitrogen as a result of climate change are affecting agricultural production in Kwali Area Council (Aregbesola, Ebele, Haastrup and Adams, 2014). Parrya, Rosenzweigb, Iglesiasc, Livermored, Fischere, (2004) named three possible negative effects of climate influence on agricultural production as loss of land, rise in sea levels, geographical shift resulting in changes in agricultural yield and availability of water for irrigation. 
Given that agriculture in Nigeria is largely dependent on rainfall, the implication is that any unfavourable change in climate is likely to impact negatively on food production. Nigeria's agriculturalists still depend majorly on rainfall to produce instead of the use of irrigation that supplies water all year round. Agricultural activities in the Nigeria are sometimes plagued by extreme weather conditions such as draught and flooding during the raining season. Unfortunately, gas flaring, rural-urban migration, industrialization and deforestation are human activities that contribute to climate change. To date, Nigeria still flares gas, rural dwellers still fell trees for cooking and heating.

Nigeria with over an estimated 196 million people (CBN, 2018 ), is the most populated country in Africa and represents about 47 percent of the population of the whole of West Africa. Agriculture is the major occupation in Nigeria, employing over $60 \%$ of the active work force and contributing over $40 \%$ of the national GDP (Food Security Portal, 2014). The economic landscape of most African countries depends essentially on the dynamics of climate change. Key sectors driving their economic performance and livelihoods such as agriculture, forestry, energy, tourism, coastal and water resources are highly vulnerable to climate change. (Babatunde and Ayodele 2015).

\section{METHODOLOGY}

The study area is Nigeria with a population of about 196 million and an area of 923,000 square kilometres (CBN, 2018). Nigeria has a variety of ecosystems; from mangroves and rainforests on the Atlantic coast in the South to the savannah in the North.

For the purpose of this study, secondary data is employed. Most of the data were computed by government agencies such as National Bureau of Statistics (NBS), Central Bank of Nigeria (CBN) and other allied organizations. The study adopts the Ordinary Least Squares technique in estimating the model specified.

\section{The functional form of the model}

AGOP $=\mathrm{f}($ GEA, RFAL, TEMP, EXR, INFL)

Where:

AGOP = Agricultural Output

GEA = Government Expenditure on Agriculture

RFAL $=$ Rainfall

TEMP $=$ Temprature

EXR $=$ Exchange Rate

INFL $=$ Inflation

The econometric form

$A G O P=\alpha_{0}+\alpha_{1} G E A+\alpha_{2} T E M P+\alpha_{3} R F A L+\alpha_{4} E X R+\alpha_{5} I N F L+\mu$

$\alpha_{0}=$ intercept

$\alpha_{0}-\alpha_{5}=$ Coefficient of the independence variables

$\mu=S$ tochastic error term (this captures all the imperfections that may be associated with the regression model and erratic features of human element).

A priori expectation, $\alpha_{0}, \alpha_{1}, \alpha_{3}, \alpha_{4}>0 ; \alpha_{2}, \alpha_{5}<0$

\section{PRESENTATION AND DISCUSSION OF RESULTS}

The regression result is presented below in Table 1 . The $t$-test statistic for ascertaining the statistical significance of the estimated coefficients is measured with conventional t-statistic levels of $1 \%, 5 \%$, and $10 \%$ respectively.

The dependent variable is the Agricultural Output (AGOP). 37 observations used for estimation range from 1981 to 2017 . The result is displayed in table 1 . 
Table1: REGRESSION RESULT

\begin{tabular}{|l|l|l|l|l|}
\hline Variable & Coefficient & Standard Error & t-Statistic & Prob. \\
\hline C & 7.4812 & 6.5048 & 2.3131 & 0.0291 \\
\hline GEA & 0.5304 & 0.1952 & 2.7166 & 0.0108 \\
\hline TEMP & -0.0315 & 0.2550 & -2.1235 & 0.0256 \\
\hline EXR & 0.0229 & 0.0045 & 5.0865 & 0.0000 \\
\hline RFAL & 3.4816 & 1.0391 & 3.4258 & 0.0142 \\
\hline & & & & \\
INFL & -0.0124 & 0.0091 & -1.8547 & 0.0656 \\
\hline
\end{tabular}

Source:

Author's

computation,

2018

\section{R-Squared $=0.92 ;$ Adjusted R-Squared $=0.89 ;$ F-Statistic $=164.76$; D-W Statistic $=1.98$}

From table 1, we tried to ascertain the joint impact of Government Expenditure on Agriculture (GEA), Temperature (TEMP), Exchange Rate (EXR), Rainfall (RFAL), and Inflation Rate (INFL) on Agricultural Output (AGOP) in Nigeria. The result showed that all the explanatory variables were correctly signed hence conformed to a priori expectations.

Furthermore, the result revealed that the five regressors or independent variables in the equation explained about $92 \%\left(\mathrm{R}^{2}=0.92\right)$ of the systematic variation in agricultural output (AGOP) during the period 1981 to 2017. While the adjusted R-squared with coefficient of determination 0.89 which demonstrates the goodness-of-fit of the model was satisfactory, showing a good explanatory power of the model. The F-Statistic which indicates the overall significance of the model was satisfactory with a coefficient of 164.76 significant at $1 \%$. This indicates a significant linear relationship between the dependent variable and the explanatory variables. This implies that overall, the model exhibited a high degree of goodness-of- fit. It can then be said that the five explanatory variables government expenditure on agriculture, temperature, exchange rate, rainfall and inflation are dependable predictors of agricultural output (AGOP) in Nigeria.

Considering the t-values of the coefficients of the explanatory variables, all were statistically significant at $5 \%$ except inflation which was significant at $10 \%$. Temperature and inflation were statistically significant at $5 \%$ and $10 \%$ level of significance respectively and both have negative impact on agricultural output. The higher the temperature the lower the yield which explains the current low output of tuber crops mainly grown in the middle belt of Nigeria. Other crops are also affected by increase in temperature because most farmers in Nigeria depend on rainfall to water their crops. A huge contribution to Nigerian Gross National Product comes from the agricultural sector and majority of the rural dwellers are employed in this sector. The important role of agriculture makes it obvious that even minor climate change can cause devastating socioeconomic consequences.

Government Expenditure on agriculture plays a key role in the agricultural productivity and sustainability especially in developing countries that depends so much on agriculture for food, raw materials and employment. From the result, GEA with a coefficient of 0.53 and a t-stat of 2.716 is significant at $5 \%$ and positively related to AGOP. From the result, $1 \%$ increase in government expenditure will result in $0.53 \%$ increase in agricultural output. In Nigeria, the agricultural sector is termed priority sector because of its importance in sustainable development. With increased government spending it is hoped that Nigeria can move from subsistence farming to mechanized farming and from agricultural product importation to exportation. Presently, budgetary allocation to the agricultural sector is still low to impact significantly on the economy. Nigeria imports tons of grains yearly worth billions of dollars while fertile acres of land lie waste.

Exchange Rate (EXR) is positively signed with a coefficient of 0.0229 and significant at $1 \%$. The higher the exchange rate, the higher the agricultural output. That is, the higher the value of the naira (with respect to the dollar) the less the cost of importation of agricultural tools and fertilizer. The agricultural sector is yet to produce 
optimally given the vast expanse of fertile and uncultivated lands in Nigeria. The cost of improved seedlings, tractors, fertilizer and others is adversely affected by the exchange rate. The low value of the Nigerian currency has made importation a night mare. Farmers are constraint to farm manually and this has hampered production. Government has made several attempts to procure improved seedlings and fertilizers and resell to peasant farmers at subsidized rates, these efforts have not boosted production significantly because over $90 \%$ of farmers do not benefit from the scheme.

Rainfall (RFAL) which is significant at 5\% with a coefficient of 3.48 shows a positive relationship with agricultural output, that is, the higher the level of rainfall the higher the output on agriculture. $1 \%$ change in rainfall will lead to about 3.5\% increase in agricultural output. Idumah et. al (2016) in their study also found that rainfall had positive relationship with agricultural output but in the short run. Droughts are getting worse and climate uncertainty is on the increase in the arid zones. Drastic reduction in rainfall is seen already in desert-prone areas in northern Nigeria causing increasing desertification. States that were known to be food baskets (e.g. Benue) of Nigeria are now experiencing huge decline in agricultural output. The southern area of Nigeria largely known for high rainfall is currently confronted by irregularity in the rainfall and rising temperature. In addition, the northern zone faces the threat of desert encroachment (FME, 2004).

Inflation rate (INFL) is negatively signed and this conformed to apriori expectation. That is, the higher the rate of inflation the lower the agricultural output. When the price of agricultural products is high, demand decreases and this translates to lower patronage hence decreased output.

The Durbin-Watson (DW) statistic of 1.98 which is the test for the presence or otherwise of autocorrelation correlation showed that it was highly minimized. Therefore, valid prediction(s) can be made from the model or the regression estimation result.

In a nutshell, the result has been able to establish the relationship between agricultural output (AGOP) and climate change in Nigeria and this is in tandem with the objective of this study.

\section{CONCLUSION}

Climate change is a global phenomenon and countries of the world are investing huge sums of money to eradicate or cushion the negative effects. Nigeria cannot afford to be a bystander, all stakeholders including the public and private sectors should seriously address the climate change by implementing the international agreements to which Nigeria is a signatory.

The study results revealed that government expenditure on agriculture, exchange rate, rainfall were not only positively related to agricultural output but were also statistically significant. Temperature and Inflation were negatively related to agricultural output and were significant at $5 \%$ and $10 \%$ respectively. The implications of these findings are that, efforts should be geared towards the enhancement of agricultural productivity in the country as it is a stimulus for economic growth. Government expenditure has a direct positive relationship to output, which means that the more the government spends on agriculture the higher would be the output. Considering the unfavourable exchange rate, positive performance of the agricultural sector will save Nigeria billions of dollars currently being spent on importation of food and raw materials.

Exchange rate has relatively been stable in recent years due to the Central Bank of Nigeria (CBN) intervention in the foreign exchange market but a lot still needs to be done to improve the value of the naira. The reduction and sustenance of stable exchange rate will further boost agricultural productivity in Nigeria.

The erratic and unpredictable nature of the weather which encapsulates the temperature and rainfall are key determinants of agricultural productivity naturally. Hence, as the results revealed, government, agencies and farmers should give the issue of climate change full throttle considering its attendant negative effects on agricultural output in Nigeria. According to Enete (2014), Climate Change is increasingly one of the most serious national security threats which will have significant impacts on natural resources, ecosystem and biodiversity. At the same time, it is likely to trigger food insecurity, human migration, economic, and social depression, environmental and political crisis, thereby affecting national development.

The major limitation to this study was the lack of adequate data that captures the real climate situation in Nigeria with reference to temperature and rainfall. We had to rely on generalized data from the Sub-Saharan region. 


\section{RECOMMENDATIONS}

In an effort to improve agricultural output in the coming years in the light of adverse climate change and especially in line with the result of this study, it is imperative:

- For government to increase its budgetary allocation to the agricultural sector, enact policies deliberately targeted at mitigating the effect of climatic change on agriculture and empower farmers via subsidies and soft loans through the relevant agencies of the State.

- For government to develop improved variety crops to be distributed to farmers at very low subsidized rate to encourage production.

- That exchange rate be stabilized and foreign exchange made available especially for importation of agricultural products and machines like tractors, harvesters, fertilizer amongst others.

- That government invests in the provision of irrigation facilities in areas where drought has set in so as to ensure an all-year-round production.

\section{REFERENCES}

Abul-Quasem A., Leal W., Trinxeria, J.M., Jaafar, A.H., \& Ghani, Z.A, (2011): Assessing the Impacts of Climate Change in the Malaysian Agricultural Sector and its Influences in Investment Decision. Middle-East Journal of Scientific Research 7 (2), 225-234

Adejuwon, S. A. (2004). Impact of climate variability and climate change on crop yield in Nigeria Contributed Paper to Stakeholders Workshop on Assessment of Impact and Adaptation to Climate Change (AIACC): 2-8

Aregbesola,, F., Ebele,U., Haastrup, D. T., \& Adams, E. (2014). The Effect of Climate Change on Agricultural Production among Farmers in Kwali Area Council of Federal Capital Territory of Nigeria. Advances in Social Sciences Research Journal Vol. 1 No.2

Aregheore, E. (2011). Country Pasture/Forage Resource Profile: Nigeria. Food and Agriculture Organization of the United Nations.

Apagu, V. V., Kwami, G. M., and Garba, E. Y. (2011). Adaptation to climate change as a challenge on agricultural production, presented at the National Conference on Climate Change at Federal University of Technology, Yola, 2011

Azih, I. (2008): A Background Analysis of the Nigerian Agricultural Sector. Oxfam Novib Economic Justice Campaign in Agriculture, Lagos.

Babatunde, A. \& Odusola, A. (2015): Climate Change and Economic Growth in Africa: An Econometric Analysis. Journal of African Economies Advance Access published January $\quad 20,2015,1-25$

Central Bank of Nigeria (2018). Statistical Bulletin. Available:http://statistics.cbn.gov.ng/cbn

Cline, W. R., (2007). Global Warming and Agriculture: New Country Estimates Show Developing Countries Face Declines in Agricultural Productivity, Center for Global Development, :1-4

Emejor, C (2018). Budgetary Allocations to Agriculture Less Than 2\% in 7 Years - CAADP Report.

Enete, I.C (2014). Impacts of Climate Change on Agricultural Production in Enugu State, Nigeria. J Earth Sci Clim Change 5: 234. Doi: 10.4172/2157-7617.1000234.

Federal Government of Nigeria (2008), Climate change: Road to coping strategies. Nigeria: Federal Ministry of Environment.

FME (2004). Federal Ministry of Environment. Food Security Portal (2014). Food Security Portal Nigeria. http://www.foodsecurityportal.org/Nigeria 
Idumah, F., Mangodo C., Ighodaro, U. \& Owombo, P. (2016): Climate Change and Food Production in Nigeria: Implication for Food Security in Nigeria. Canadian Center of Science and Education Journal of Agricultural Science; Vol. 8, No. 2; 2016

Intergovernmental Panel on Climate Change (ICPC, 2007) Impacts, Adaptation and Vulnerability. Asia Climate Change 2007. Parry M.L, Canziani O.F, Palutikof JP, van der Linden P.J, Hanson C.E (edn.). Cambridge University Press, Cambridge, UK 469-506.

IPCC. (2007). Climate Change: Synthesis Report. Contributions of Working Groups I, Ii, and Iiito the Fourth Assessment Report of the Intergovernmental Panel on Climate Change. Geneva

Kuta, D. A.(2011). Nigeria: Climate change and agriculture in Nigeria, Global Environment Change., vol. 14, pp. 273-282,

Kurukulasuriya, P., \& Mendelsohn, R. (2007). A Ricardian analysis of the impact of climate change on Africa Cropland. World Bank Policy Research Paper No. 4305. World Bank, Washington D.C.

Manyong, V. M., Ikpi, A., Olayemi J., Yusuf, S., Omonoma B., Okoruwa V, \& Idachaba, F. (2005). Agriculture in Nigeria: Identifying Opportunities for Increased Commercialization and Investment in USAID/IITA/UI Project Report Ibadan, Nigeria.

Mohammed-Lawal, A. \& Atte, O.A (2006). An Analysis of Agricultural Production in Nigeria. African Journal of General Agriculture, 2(1): 1-6.

Molua, E. L. (2009). An Empirical Assessment of the Impact of Climate Change on Smallholder Agriculture in Cameroon. Global and Planetary Change, Vol.67: 205-208.

Parrya, M.L., Rosenzweigb, C., Iglesiasc, A., Livermored, M. \& Fischere, G. (2004). Effects of Climate Change on Global Food Production Under SRES Emissions and Socio-Economic Scenarios. Global Environmental Change 14 53-67. Hadley Centre, UK Meteorological Office, Fitzroy Road, Exeter EX1 3PB, UK Goddard Institute for Space Studies, New York City, USA.

Seo, N., \& Mendelsohn, R. (2008). A Ricardian Analysis of the Impact of Climate Change on South American Farms. Chilean Journal of Agricultural Research 68: 69-79.

Warren, A. (2005). The Policy Implications of Sahelian Change. Journal of Arid Environments, Vol.63: 660-670 https://www.independent.ng/budgetary-allocations-to-agriculture-less-than-2-in-7-years-caadpreport/https://www.google.com/search?ei=NE5XXJrF8bFwAKrzL5I\&q=nigeria + population $+a s+a t+2018 \& o q=$ nigeria + population $+a s+a t+2018 \& g s \quad 1=p s y-$ ab.12...0.0..1037...0.0..0.0.0......0.....gws-wiz.wqR8w-MODaE 